\title{
Discriminating Typical and Atypical Cystic Fibrosis-Related Bacteria by Multiplex PNA-FISH
}

\author{
Susana P. Lopes, ${ }^{1}$ Daniel T. Carvalho, ${ }^{2}$ Maria O. Pereira, ${ }^{1}$ Nuno F. Azevedo ${ }^{2}$ \\ ${ }^{1}$ Centre of Biological Engineering, LIBRO_Laboratório de Investigação em Biofilmes \\ Rosário Oliveira, University of Minho, Campus de Gualtar, 4710-057 Braga, Portugal; \\ telephone: +351 253601 969; fax: +351 253604 429; e-mail: supat@deb.uminho.pt \\ ${ }^{2}$ LEPABE, Faculty of Engineering, Department of Chemical Engineering, University of \\ Porto, Porto, Portugal
}

ABSTRACT: This study aims to report the development of peptide nucleic acid (PNA) probes to specifically detect the cystic fibrosis (CF)-associated traditional and atypical species Pseudomonas aeruginosa and Inquilinus limosus, respectively. PNA probes were designed in silico, developed and tested in smears prepared in phosphate-buffer saline (PBS), and in artificial sputum medium (ASM). A multiplex fluorescent in situ hybridization (FISH) approach using the designed probes was further validated in artificially contaminated clinical sputum samples and also applied in polymicrobial $24 \mathrm{~h}$-old biofilms involving $P$. aeruginosa, I. limosus, and other CF-related bacteria. Both probes showed high predictive and experimental specificities and sensitivities. The multiplex PNA-FISH assay, associated with non-specific staining, was successfully adapted in the clinical samples and in biofilms of CF-related bacteria, allowing differentiating the community members and inferring about microbial-microbial interactions within the consortia. This study revealed the great potential of PNAFISH as a diagnostic tool to discriminate between classical and less common CF-associated bacteria, being suitable to further describe species-dependent prevention strategies and deliver more effective target control therapeutics.

Biotechnol. Bioeng. 2017;114: 355-367.

(C) 2016 Wiley Periodicals, Inc.
Conflicts of interest: None.

Correspondence to: S.P. Lopes

Contract grant sponsor: FCT, COMPETE 2020, FEDER, PT2020

Contract grant number: UID/BIO/04469/2013

Contract grant sponsor: FCT/MEC, FEDER, PT2020

Contract grant number: UID/EQU/00511/2013-LEPABE

Contract grant sponsor: COMPETE 2020

Contract grant number: POCI-01-0145-FEDER-006684

Contract grant sponsor: FCT

Contract grant number: RECI/BBB-EBI/0179/2012 (FCOMP-01-0124-FEDER-027462)

Contract grant sponsor: QREN, FEDER, ON2

Contract grant number: NORTE-07-0124-FEDER-000027

Contract grant sponsor: FEDER, ON2, FCT/MEC

Contract grant number: NORTE-07-0124-FEDER-000025

Contract grant sponsor: COST-Action TD1004

Received 27 May 2016; Revision received 15 August 2016; Accepted 22 August 2016

Accepted manuscript online 29 August 2016;

Article first published online 26 September 2016 in Wiley Online Library

(http://onlinelibrary.wiley.com/doi/10.1002/bit.26085/abstract).

DOI 10.1002/bit.26085
KEYWORDS: cystic fibrosis microbiome; fluorescence in situ hybridization; Inquilinus limosus; PNA probe; Pseudomonas aeruginosa

\section{Introduction}

Cystic fibrosis (CF) is a genetic disorder affecting multiple organs, but with a high incidence and frequency in the respiratory system. The CF pulmonary disease is characterized by viscous secretions and airways obstruction, contributing to high rates of mortality in $\mathrm{CF}$ individuals due to the respiratory failure. Additionally, the favorable environment that is created in the airways of CF patients (containing dehydrated mucus, products resulting from inflammatory cell death, steep oxygen gradients, etc.) often encourages a complex microbiome to persistently colonize and to cause severe chronic infections since early in the life (Davies and Bilton, 2009; Gomez and Prince, 2007; Lopes et al., 2015; Ratjen, 2009). A limited number of microbial species (Staphylococcus aureus, Haemophilus influenza, Pseudomonas aeruginosa, and Burkholderia cepacia complex (BCC) group) has been considered responsible for bacterial lung infections, of which $P$. aeruginosa is recognized as the most significant pathogen and the most commonly isolated organism (Burns et al., 1998; Hoiby, 2011; Lambiase et al., 2006; Lipuma, 2010). However, the respiratory tract of CF patients does not harbor a simple microbiological flora. A wide number of atypical bacteria (e.g., Inquilinus limosus, Stenotrophomonas maltophilia, Dolosigranulum pigrum, Achromobacter xylosoxidans, and other species) are now well recognizable, but its identification by routine cultivation methods and biochemical tests remain unreliable (Lopes et al., 2015; Stressmann et al., 2011).

The recent focus has led to the recognition that these microorganisms may co-exist and interact with the traditional species, and also with the host immune system, affecting the disease progression and treatment routes (Magalhães et al., 2016). But while the impact of some of these unusual microorganisms in the CF infection is starting to be elucidated (Costello et al., 2011; Dalboge et al., 2011; Hansen et al., 2010; Lopes et al., 2012; Pompilio 
et al., 2010; Rolain et al., 2009; Ulrich et al., 2010; Waters et al., 2013), the pathogenic potential of others has yet to be fully understood. I. limosus, an $\alpha$-proteobacterium has been constantly emerging from the airways of CF patients (Chiron et al., 2005; Cooke et al., 2007; Pitulle et al., 1999; Salvador-Garcia et al., 2013; Schmoldt et al., 2006; Wellinghausen et al., 2005). Because of the mucoid physiology, the multi-drug resistance character and the ability to persist in the respiratory tract after biofilm formation (Bittar and Rolain, 2010; Chiron et al., 2005), this bacterium is now considered a potential threat for $\mathrm{CF}$ pathogenesis, which makes its identification desirable.

The classical identification and characterization of bacterial isolates in many microbiology laboratories and/or hospital centers rely solely on cultivation of pathogens and phenotypic techniques, which carry out a wide number of problems. Firstly, these techniques generally require at least $1-3$ or more days for definitive detection of a bacterial species, preventing or delaying effective infection control strategies and therapeutic interventions (Anuj et al., 2009; Hogardt et al., 2000; Saiman and Siegel, 2004). This time-gap is extended for organisms that are fastidious, slow growing, noncultivable, or present as part of polymicrobial infections (Wolk and Dunne, 2011), as often occurs in CF. Additionally, these methods usually lead to the misidentification of unusual bacteria that improperly grow on unsuitable selective media and also fail in detecting microorganisms with compromised growth properties (e.g., after antibiotic therapy), and/or even anaerobic microorganisms, which require specific growth conditions (Bittar and Rolain, 2010; Bousbia et al., 2013; Galluzzi et al., 2007). Also, a range of different unusual species can grow in the same selective media used for the detection of other organisms, leading to misidentification (it is the case of I. limosus that grows in the Burkholderia cepacia selective medium) when using culturing methods (Bittar et al., 2008a; Kidd et al., 2009; Spilker et al., 2008).

Over the last 2 decades, there has been a significant progress on the development of rapid techniques (e.g., quantitative polymerase chain reaction-qPCR, 16S rRNA gene sequencing, denaturing/ temperature gradient gel electrophoresis-DGGE/TGGE, terminal restriction fragment length polymorphism-T-RFLP, and matrixassisted laser desorption ionization-time of flight mass spectrometry-MALDI-TOF MS) to detect, identify, and/or quantify microorganisms within polymicrobial communities (Bittar et al., 2008b; Fernandez-Olmos et al., 2012; Guss et al., 2011; KirketerpMoller et al., 2008; Lambiase et al., 2013; Malic et al., 2009; Rogers et al., 2003, 2004; Sibley et al., 2006). These promising molecular approaches have been developed to complement or even replace existing typical microbiological methods and other practices (Amann et al., 1995; Barenfanger et al., 1999; Call et al., 2003; Chadwick et al., 1998; Cleven et al., 2006; Hiyari and Bennett, 2011), highly improving the diagnosis of microbial species, providing more rapid, specific and sensitive systems than culture-dependent methods (Oosterheert et al., 2005), facilitating the identification of microorganisms present in biofilms (Bittar and Rolain, 2010; Galluzzi et al., 2007), and detecting abundant numbers of bacteria that do not grow under culture but are still viable (Hugenholtz, 2002; Oliver, 2005). It has been in this context that PNA FISH has emerged as a valuable tool for the specific and rapid detection of bacteria in polymicrobial communities without the need of cultivation (Almeida et al., 2010). PNA oligonucleotide probes are synthetic DNA analogue molecules, with the main difference residing in the backbone of the molecule. While DNA possesses a negatively charged sugar-phosphate backbone, the PNA molecule consists of repeating $\mathrm{N}$-(2-aminoethyl)glycine units, resulting in an achiral and neutral backbone (Nielsen, 2001; Nielsen et al., 1991). This enables PNA molecules to better penetrate through the cell wall and cell membrane of the target microorganism, and specifically hybridize with the complementary rRNA sequence, according with the Watson and Crick base-pairing rules (Stender, 2003). In general, PNA oligonucleotide probes are small (13-18 bp in length) and are covalently labeled with a fluorescent dye molecule (e.g., fluorescein, carbocyanine), becoming easily detected by epifluorescence microscopy or flow cytometry (Almeida et al., 2011; Azevedo et al., 2011; Cerqueira et al., 2008). In comparison with other reference methods currently used in clinical microbiology, FISH has many advantages. For example, it does not require DNA extraction and purification, which are a prerequisite before PCR amplification and may cause sample contamination (Yang and Rothman, 2004). Unlike in PCR, FISH may be carried out in situ (Aslanzadeh, 2004), which makes this technique particularly suitable when applied to biofilms. In fact, as it is not needed to disrupt attached cells, it allows in-depth characterization of microbial composition, hence, deducing about the complex microbial-microbial (Almeida et al., 2011) and microbial-host interplay (Thornton et al., 2011). While MALDI-TOF MS assay is widely used because of its high accuracy, versatility, cost-efficient, and speed of analysis benefits, the method is limited in that it requires subculture before identification. As whole intact cells are typically used in the analysis, abundant number of bacterial cells are needed (which are often low when working with biological fluids) (Wolk and Dunne, 2011). Additionally, MALDI-TOF MS-based sequencing for the detection of antibiotic resistance determinants appears to be labor-intensive and limited by the small size of the DNA fragments that can be sequenced and the technique is often unable to identify antimicrobial resistance determinants (Josten et al., 2013). By the contrary, FISH-based methods have been showing promising results since they can detect intact bacterial cells directly in clinical samples (tissues, blood, sputum, etc.), or even after an enrichment step (Almeida et al., 2010; Mothershed and Whitney, 2006; Trebesius et al., 2000). Moreover, the detection and location of resistant microorganisms directly within biological samples is made possible with FISH methods (Cerqueira et al., 2011). Therefore, FISH appears suitable and easily-to-handle for integration in a clinical microbiology laboratory, only requiring basic technical equipment (an epifluorescent microscope) equipped with an adequate set of filters for fluorochromes. FISH using labeled fluorescent PNA probes has long been used in many fields of microbiology, with some reports being extended to the analysis of pathogens in CF samples (Bjarnsholt et al., 2009; Brown and Govan, 2007; Hogardt et al., 2000; Malic et al., 2009; Rudkjobing et al., 2012; Wellinghausen et al., 2006; Yang et al., 2008). But while a complex microbial diversity is invariably present in CF lungs, reports using PNA-FISH only detect the classical CF-pathogens, preventing an accurate identification of the complex microbial community present within the CF environment and subsequently a full understanding of the bacterial interactions occurring in situ as well as the interplay 
of these communities in the host. Moreover, aggregates of bacteria encased in a self-produced extracellular matrix, the so-called biofilms, are found in the CF airways. In these consortia, bacteria become more tolerant to antibiotic treatments and resistant to host immune responses compared to their planktonic, free-living counterparts. Therefore, detection and identification of biofilms in $\mathrm{CF}$ are crucial to design better treatment strategies aiming to eradicate these biofilms.

The goal of this study was to develop labeled multiplex PNAFISH method for the specific identification and localization of the CF-associated traditional organism $P$. aeruginosa, and the emergent species I. limosus. Subsequently, the applicability of a multiplex PNA assay was assessed to discriminate the aforementioned bacteria within mixed-species biofilms formed by traditional and atypical bacterial species found in $\mathrm{CF}$.

\section{Material and Methods}

\section{Design, Synthesis, and Preparation of the PNA Oligonucleotide Probes}

Two novel PNA probes to specifically detect the CF-associated organisms $P$. aeruginosa and I. limosus were designed according to the methodology described before (Almeida et al., 2010; Azevedo et al., 2011). In short, the freely accessible PrimRose software (Ashelford et al., 2002) in conjunction with the 16S rRNA databases of Ribosomal Database Project II (RDP II) version 10.0 (Cole et al., 2005) were used to identify useful oligonucleotide sequences for each target organism. After the assessment of a limited number of potential oligonucleotide probes for each organism, the final selection of each PNA probe sequence was based on the criteria described by Azevedo et al. (2011). Nonetheless, for multiplex purposes, both PNA probes should present similar melting temperatures (determined according to the model proposed by Giesen et al. (1998).

The following $15 \mathrm{bp}$-length PNA oligomer sequences were selected: $5^{\prime}$-GCTGAACCACCTACG- $3^{\prime}$ and $5^{\prime}$-CCCGCCCGTATC AAA- $3^{\prime}$ for $P$. aeruginosa and $I$. limosus, respectively. The probes were designated as Paer565 and Ilim569, because of the starting position of the target $16 \mathrm{~S}$ rRNA sequence of the strains P. aeruginosa ATCC 27853 (Accession number S0005765) and I. limosus AU430 (Accession number S000434854), respectively.
Finally, both probe sequences were synthetized by Panagene (Daejeon, South Korea), and each oligonucleotide N-terminus was attached to a fluorochrome (Alexa 594 and Alexa 488 for Paer565 and Ilim569, respectively), via a double 8-amino-3, 6-dioxaoctanoic acid (AEEA) linker. The stock solution (at $100 \mathrm{mM}$ ) of each PNA probe was obtained by solubilizing the powder in $10 \%$ ( $\mathrm{vol} / \mathrm{vol})$ of acetonitrile and $1 \%(\mathrm{vol} / \mathrm{vol})$ of trifluoracetic acid, and stored at $-20^{\circ} \mathrm{C}$. The working solutions (at $200 \mathrm{nM}$ ) were prepared in hybridization solution containing $10 \%$ (wt/vol) dextran sulphate, $10 \mathrm{mM} \mathrm{NaCl}, 30 \%$ (vol/vol) formamide, $0.1 \%$ (wt/vol) sodium pyrophosphate, $0.2 \%(\mathrm{wt} / \mathrm{vol})$ polyvinylpyrrolidone, $0.2 \%$ (wt/vol) Ficol, $5 \mathrm{mM}$ disodium EDTA, 0.1\% (vol/vol) Triton X-100, and $50 \mathrm{mM}$ Tris-HCl (all purchased from Sigma-Aldrich, Sintra, Portugal) and stored at $4^{\circ} \mathrm{C}$ for further use.

\section{Optimization of the Hybridization Conditions}

The hybridization procedure was optimized on pure smears of the CF-associated organisms $P$. aeruginosa (wild type strain UCBPP PA14) and I. limosus (strain M53, isolated from CF sputum). Every 2 or 3 days, single colonies of each strain were streaked onto fresh media containing tryptic soy broth (TSB; Liofilchem, Teramo, Italy) supplemented with $1.2 \%$ (wt/vol) agar (Liofilchem). The plates were aerobically incubated at $37^{\circ} \mathrm{C}$ for $18-20 \mathrm{~h}$ (for P. aeruginosa) or $\sim 48 \mathrm{~h}$ (for I. limosus). The FISH procedure on smears was previously described by Cerqueira et al. (2011). Since the purpose was to further apply the multiplex assay to CF mixed-species populations, the hybridization conditions should be similar for both probes. Thus, a set of different hybridization temperatures was tested for each probe, with Paer565 and Ilim569 showing the brightest fluorescent signal at $65^{\circ} \mathrm{C}$ (data not shown).

After selecting the optimal hybridization temperature, a multiplex (three-species) assay encompassing $P$. aeruginosa, $I$. limosus, and other CF-related species was assessed. For this, one CF-classical species (Burkholderia multivorans, LMG 13010) and two atypical bacteria (A. xylosoxidans, a CF clinical isolate, and also D. pigrum, CIP 104051) were used. The third organism was identified by counterstaining the samples with $4^{\prime}$, 6-diamidino-2phenylindole (DAPI; Sigma) at the end of the hybridization procedure. Basically, the mixed bacterial suspensions were prepared in phosphate-buffer saline (PBS) solution by adding the three species ( $P$. aeruginosa, I. limosus, and each of the other strains) in

Table I. PNA oligonucleotide probe sequences designed for $P$. aeruginosa and $I$. limosus and the respective predicted specificities and sensitivities.

\begin{tabular}{|c|c|c|c|c|c|c|c|}
\hline Probe* & $\begin{array}{c}\text { Target } \\
\text { microorganism }\end{array}$ & $\begin{array}{l}\text { Probe sequence } \\
\qquad\left(5^{\prime}-3^{\prime}\right)\end{array}$ & $\begin{array}{l}\text { No. of targets } \\
\text { detected }^{\mathrm{a}}\end{array}$ & $\begin{array}{l}\text { No. of non-targets } \\
\text { detected }^{\mathrm{b}}\end{array}$ & $\begin{array}{l}\text { Specificity } \\
(\%)^{c}\end{array}$ & $\begin{array}{l}\text { Sensitivity } \\
(\%)^{\mathrm{d}}\end{array}$ & Reference of source \\
\hline Paer565 & P. aeruginosa & GCTGAACCACCTACG & 892 & 458 & 99.7 & 90.3 & This study \\
\hline Ilim569 & I. limosus & CCCGCCCGTATCAAA & 7 & 11 & 100.0 & 87.5 & This study \\
\hline Psaer & P. aeruginosa & AACTTGCTGAACCAC & 898 & 447 & 99.7 & 90.8 & $\begin{array}{l}\text { Coull and Hyldig-Nielsen } \\
\text { (2003) }\end{array}$ \\
\hline Pse16S32 & P. aeruginosa & CTGAATCCAGGAGCA & 805 & 727 & 99.5 & 81.5 & Perry-0'Keefe et al. (2001) \\
\hline
\end{tabular}

*All probes were designed to complement with the 16S rRNA target.

${ }^{a}$ Number of target microorganisms detected by each probe in a total of 988 P. aeruginosa and eight $I$. limosus strains sequences presented in the database.

${ }^{\mathrm{b}}$ Number of non-target microorganisms detected by each probe in a total of 178996 non-P. aeruginosa and 179976 non-I. limosus sequences deposited in the database.

${ }^{\mathrm{c}}$ Given by (no. of non-targets excluded by the probe)/(total of non-targets in the database) $\times 100$.

${ }^{\mathrm{d}}$ Given by (no. of targets detected by the probe) $/($ total no. of target organisms found in the database) $\times 100$. 
equal proportions. Afterward, $20 \mu \mathrm{L}$ were transferred to each well of $8 \mathrm{~mm}$ well glass slides (ThermoScientific, Braunschweig, Germany) and allowed to air dry. Subsequently, $30 \mu \mathrm{L}$ of each solution of $4 \%$ (wt/vol) paraformaldehyde followed by $50 \%$ (vol/vol) ethanol was dispensed in the wells for $10 \mathrm{~min}$ each and allowed to air dry. This step enables the fixation of the cells and increase the permeabilization of the cell membrane to the subsequent hybridization allowing the labeled oligonucleotide probes to diffuse to their intracellular rRNA target molecules (Amann and Fuchs, 2008). Afterward, $20 \mu \mathrm{L}$ of hybridization solution containing the probes mixture at $200 \mathrm{nM}$ were dispensed on the smears, which were finally covered with coverslips and incubated in the dark for $1 \mathrm{~h}$ at $65^{\circ} \mathrm{C}$. After hybridization, the coverslips were carefully removed and the slides were submersed for $30 \mathrm{~min}$ in coplin jars containing a prewarmed $\left(65^{\circ} \mathrm{C}\right)$ washing solution composed of $5 \mathrm{mM}$ Tris Base, $15 \mathrm{mM} \mathrm{NaCl}$ and $1 \%$ (vol/vol) Triton X-100 (all from Sigma). Finally, the slides were removed from the coplin jars and allowed to air dry before counterstaining with DAPI at $40 \mu \mathrm{g} / \mathrm{mL}$. Negative controls were performed for each experiment, with no probes added to the hybridization solution. Next, the same procedure was also tested in the aforementioned mixed smears diluted in artificial sputum medium (ASM), which was prepared as described by Sriramulu et al. (2005). For microscopic visualization, a fluorescence microscope (Olympus BX51, Perafita, Portugal) equipped with the filters sensitive to DAPI (BP 365-370, FT 400, LP 421) and to the signaling molecule of the PNA probes (BP 470-490, FT 500, LP 516, and BP 530-550, FT 570, LP 591, for Alexa 488 and 594, respectively) was used.

\section{Evaluation of Experimental Specificity and Sensitivity of the Probes}

In order to test the specificity and sensitivity of both probes, a set of different strains was tested at the optimal hybridization temperature previously determined $\left(65^{\circ} \mathrm{C}\right)$. All strains were maintained and incubated as mentioned above, with exception of Pseudomonas putida, which was grown at $30^{\circ} \mathrm{C}$. The presence of a strong fluorescent signal provided by each probe was assessed by microscopy and the FISH outcome was classified as "-" for a nonfluorescent signal and as "+" for a fluorescent signal.

\section{Application of FISH Method to Clinical Sputum Samples and to Mixed-Species Biofilms}

In order to assess the applicability of PNA-FISH on real context situations, sputum clinical samples were obtained from Hospital de Braga (Braga, Portugal) and artificially contaminated with mixed cultures of $P$. aeruginosa, I. limosus, and each atypical species (D. pigrum and A. xylosoxidans). The procedure used in here was similar to that previously described for smears. Equally, for biofilms, a multiplex assay was tested on $24 \mathrm{~h}$-old biofilms of $P$. aeruginosa, I. limosus, and the emerging species D. pigrum formed on polystyrene (PS) coupons. For this, the material supports were previously submerged $3 \mathrm{~min}$ in a commercial detergent solution (Sonasol, Henkel Ibérica Portugal, Bobadela, Portugal), washed three times in sterile ultrapure water and allowed to air dry for $3 \mathrm{~h}$. The biofilms were formed as described before (Lopes et al., 2012), with slight modifications. Briefly, cell suspensions of each organism containing $1 \times 10^{7}$ cells $/ \mathrm{mL}$ were prepared in TSB. The inoculum used to form the mixed-species biofilms was obtained by adding each pure suspension in equal proportions. The final inoculum was then dispensed in 24-well plates (Orange Scientific, Braine-l'Alleud, Belgium) containing the PS coupons on the bottom of the wells.

Table II. Outcome of the PNA-FISH method obtained for the $P$. aeruginosa (Paer565) and I. limosus (Ilim569) probes in the experimental specificity tests.

\begin{tabular}{|c|c|c|}
\hline Strain & Paer565 & $\operatorname{Ilim} 569$ \\
\hline Achromobacter xylosoxidans (CF isolate 1) & - & - \\
\hline Achromobacter xylosoxidans (CF isolate 2) & - & - \\
\hline Achromobacter xylosoxidans (CF isolate 3) & - & - \\
\hline Achromobacter xylosoxidans (CF isolate 4) & - & - \\
\hline Achromobacter xylosoxidans (CF isolate 5) & - & - \\
\hline Achromobacter xylosoxidans (CF isolate 6) & - & - \\
\hline Achromobacter xylosoxidans (CF isolate 7) & - & - \\
\hline Achromobacter xylosoxidans (CF isolate 8) & - & - \\
\hline Achromobacter xylosoxidans (CF isolate 9) & - & - \\
\hline Achromobacter xylosoxidans (CF isolate 10) & - & - \\
\hline Acinetobacter baumannii (clinical isolate) ${ }^{\mathrm{a}}$ & - & - \\
\hline Burkholderia cenocepacia (LMG 16656) & - & - \\
\hline Burkholderia cenocepacia (LMG 18863) & - & - \\
\hline Burkholderia dolosa (LMG 18943) & - & - \\
\hline Burkholderia multivorans (LMG 13010) & - & - \\
\hline Burkholderia stabilis (LMG 14294) & - & - \\
\hline Burkholderia sp. (clinical isolate) ${ }^{\mathrm{b}}$ & - & - \\
\hline D. pigrum (CIP 104051) & - & - \\
\hline Escherichia coli (ATCC 25922) & - & - \\
\hline Inquilinus limosus $(\mathrm{CF} \text { isolate } \mathrm{M} 53)^{\mathrm{c}}$ & - & + \\
\hline Inquilinus limosus (CF isolate 2) & - & + \\
\hline Klebsiella oxytoca (ATCC 13182) & - & - \\
\hline Klebsiella pneumoniae (clinical isolate) ${ }^{\mathrm{a}}$ & - & - \\
\hline P. aeruginosa (ATCC 10145) & + & - \\
\hline P. aeruginosa (ATCC 27853) & + & - \\
\hline P. aeruginosa (ATCC 39324$)$ & + & - \\
\hline P. aeruginosa (clinical isolate 1$)^{\mathrm{d}}$ & + & - \\
\hline P. aeruginosa (clinical isolate 2$)^{\mathrm{b}}$ & + & - \\
\hline$P$ aeruginosa (clinical isolate 3$)^{\mathrm{a}}$ & + & - \\
\hline P. aeruginosa (clinical isolate 4$)^{\mathrm{a}}$ & + & - \\
\hline P. aeruginosa (clinical isolate 5$)^{\mathrm{e}}$ & + & - \\
\hline P. aeruginosa (clinical isolate 6$)^{\mathrm{e}}$ & + & - \\
\hline P. aeruginosa $(\text { clinical isolate } 7)^{\mathrm{e}}$ & + & - \\
\hline P. aeruginosa (clinical isolate 8$)^{\mathrm{e}}$ & + & - \\
\hline$P$ aeruginosa (UCBPP-PA14) & + & - \\
\hline P. aeruginosa (PAO1) & + & - \\
\hline P. fluorescencens (ATCC 13525) & - & - \\
\hline P. fragi (food isolate) ${ }^{\mathrm{f}}$ & - & - \\
\hline P. putida (environmental isolate) ${ }^{\mathrm{f}}$ & - & - \\
\hline Staphylococcus aureus (ATCC 25923) & - & - \\
\hline Staphylococcus aureus (JKD 6008) & - & - \\
\hline Staphylococcus aureus (MRSA) $)^{\mathrm{b}}$ & - & - \\
\hline Stenotrophomonas maltophilia (CF isolate 1) & - & - \\
\hline Stenotrophomonas maltophilia (CF isolate 2) & - & - \\
\hline Stenotrophomonas maltophilia (CF isolate 3 ) & - & - \\
\hline Stenotrophomonas maltophilia (CF isolate 4) & - & - \\
\hline Stenotrophomonas maltophilia (CF isolate 5) & - & - \\
\hline Stenotrophomonas maltophilia (CF isolate 6) & - & - \\
\hline Stenotrophomonas maltophilia (CF isolate 7) & - & - \\
\hline Stenotrophomonas maltophilia (CF isolate 8) & - & - \\
\hline
\end{tabular}

${ }^{\mathrm{a}}$ Isolated from expectoration (Hospital de Braga, Portugal).

bIsolated from urinary tract, kindly provided by Margarida Martins (University of Minho, Braga, Portugal).

${ }^{c}$ Isolated from CF sputum, kindly provided by Dr. Michael G. Surette (University of Calgary, Alberta, Canada).

${ }^{\mathrm{d}}$ Isolated from an endoscope (Paris, France).

eIsolated from the urinary tract (Clínica de São Lázaro, Braga, Portugal).

${ }^{\mathrm{f}}$ Kindly provided by Hugo Oliveira (University of Minho, Braga, Portugal). 


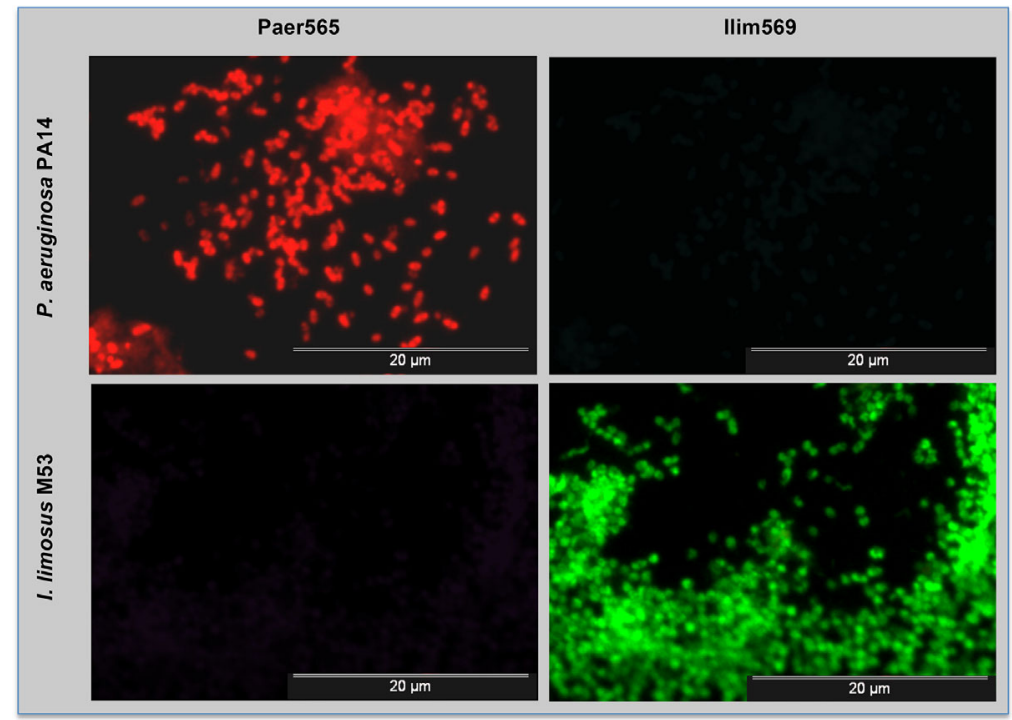

Figure 1. Detection of $P$. aeruginosa PA14 and I. limosus M53 by the red and green fluorescent probes Paer565 and llim569 in pure smears of each organism. The microscopy filters used to visualize each fluorochrome are represented on each column (left: Alexa 594; right: Alexa 488). No cross-hybridization was observed between the two PNA probes. Both images were obtained using the same exposure time.

Plates were incubated aerobically for $24 \mathrm{~h}$, at $37^{\circ} \mathrm{C}$ and $120 \mathrm{rpm}$. Afterward, biofilms adhered to the coupons were washed with sterile distilled-water and dried at $\sim 60^{\circ} \mathrm{C}$ for $15 \mathrm{~min}$. Biofilms were finally fixed with methanol $(100 \% \mathrm{vol} / \mathrm{vol})$ for $20 \mathrm{~min}$. The initial step of fixing the biofilm with methanol is crucial to avoid the detachment of bacterial cells during the hybridization procedure (Almeida et al., 2011). The FISH protocol was identical to the one applied for slides. Fixed biofilms were stored at $4^{\circ} \mathrm{C}$ for a maximum of $48 \mathrm{~h}$ before the multiplex PNA procedure.

\section{Results and Discussion}

\section{Probes Design}

In the present study, two novel PNA probes to specifically detect and localize the CF-classical opportunist $P$. aeruginosa and the atypical species I. limosus within multi-species populations were developed. Although a suitable number of studies have employed PNA probes for targeting P. aeruginosa (Peleg et al., 2009; Perry-O'Keefe et al., 2001; Rudkjobing et al., 2012), to the author's knowledge, no probes have been developed that specifically target I. limosus. A possible reason for this dissimilarity in the number of reports is because $P$. aeruginosa is often the dominant organism in lungs with advanced chronic stage disease. By contrary, other bacteria are found in small amounts, with researchers considering them as contaminants (Rudkjobing et al., 2011, 2012). Nonetheless, this scenario might not represent the other stages of the infection in the CF lungs, as shifts from clinically stability to episodes of exacerbations may lead to alterations in the airway microbiome composition (Carmody et al., 2013). Additionally, disease-derived factors (e.g., antibiotic selective pressure) and/or other perturbations (e.g., changes in $\mathrm{pH}$, temperature oxygen) may lead to a "natural selection" of the community present in the CF lungs (Conrad et al., 2013; Lynch and Bruce, 2013).

Table I summarizes the predicted theoretical specificities and sensitivities obtained for both designed probes and calculated as previously described by Guimarães et al. (2007), with some modifications. Specificity and sensitivity are two of the most important parameters to take into account during probe design. Specificity is expressed as $\mathrm{NT}_{\text {excluded }} /\left(\mathrm{NT}_{\text {database }}\right) \times 100$, where $\mathrm{NT}_{\text {excluded }}$ stands for the number of non-targets (i.e., nonmicroorganism of interest strains) that did not react with the probe and $\mathrm{NT}_{\text {database }}$ is the total of non-microorganism of interest strains examined. Sensitivity is calculated as $\mathrm{T}_{\text {detected }} /$ $\left(\mathrm{T}_{\text {database }}\right) \times 100$, where $\mathrm{T}_{\text {detected }}$ stands for the number of targets (i.e., microorganism of interest strains) detected by the probe and $\mathrm{T}_{\text {database }}$ is the total number of targets present in the databases (that did not react with the probe) (Almeida et al., 2010; Azevedo et al., 2007). For the estimation of the probe parameters, a search on the Probe Match program (from the RDP II software) was performed, where only sequences with high quality and more than $1200 \mathrm{bp}$ were considered. For comparison purposes with Paer565, other probes earlier developed for P. aeruginosa (Coull and Hyldig-Nielsen, 2003; Perry-O'Keefe et al., 2001) were also evaluated with the Probe Match (Table I). The search confirmed high theoretical specificity ( 99.7\%) and sensitivity ( 90.7\%) for Paer565. Both other probes already described for $P$. aeruginosa detection presented similar predicted specificities between each other and Paer565. However, the sensitivity of Paer565 probe was significantly higher than that obtained for Pse16S32 (81.5\%). The evolution dynamics of the databases since these probes were designed, with the constant introduction of new RNA sequences that may also be 
(A)

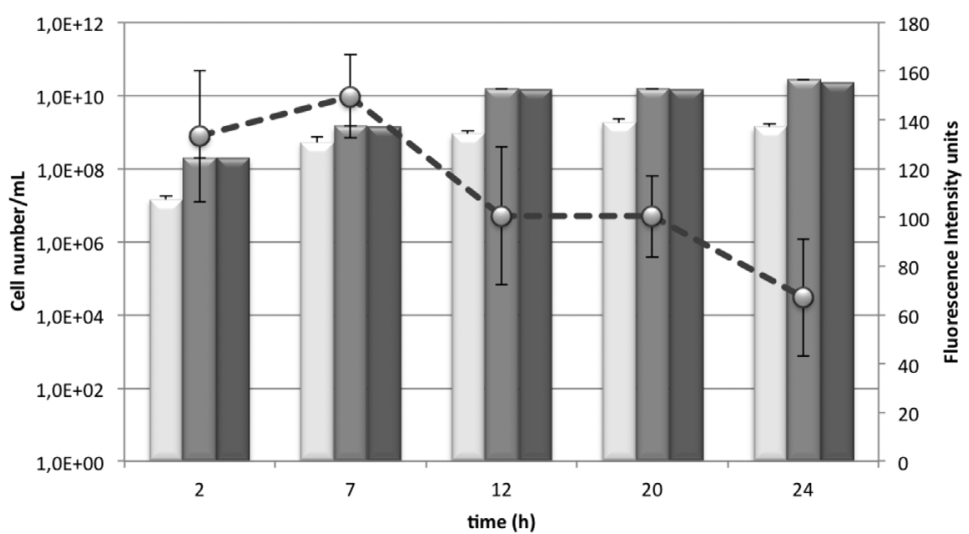

(B)
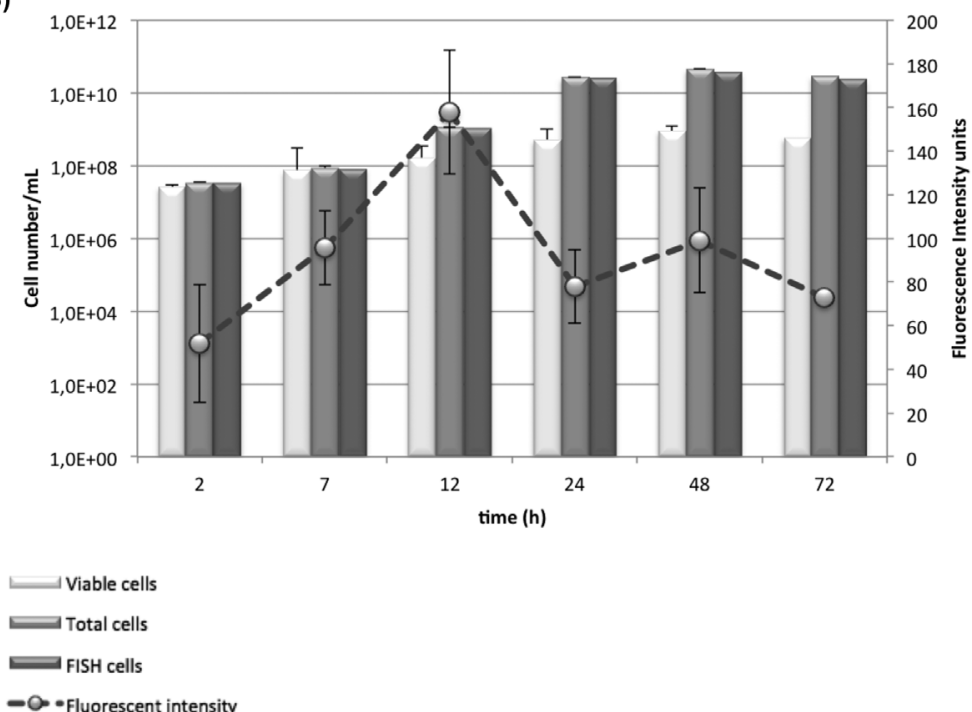

Figure 2. Correlation between cultivable (light gray columns), total (medium gray columns), FISH cells (dark gray columns), and mean intensity fluorescent signal (dashed line) in planktonic suspensions of $P$. aeruginosa (A) and $I$. limosus (B). Cultivable cells were quantified by conventional culture techniques and total cells were determined by DAPI. Data were expressed as cell number $/ \mathrm{mL}$. The intensity of FISH signal (expressed as arbitrary fluorescence intensity units) was monitored throughput the time by an adapted version of the MacBiophotonics ImageJ software.

complementary with the sequences of those probes, help to explain the decreasing sensitivities to detect $P$. aeruginosa. The probe designed by Perry-O'Keefe et al. (2001) presents a reasonable theoretical sensitivity, but it is able to hybridize with other bacterial species frequently isolated from CF samples, Burkholderia cepacia and Klebsiella sp., thus, invalidating its use in CF settings. The theoretical sensitivity obtained for Paer565 was similar to that obtained for the patented probe Psaer (Coull and Hyldig-Nielsen, 2003). Within the $988 P$. aeruginosa sequences deposited in the database, Paer565 is specific for 892 whereas, Psaer detects $898 P$. aeruginosa strains. Paer565 is able to detect other bacteria (in a total of 458), namely bacteria from different filo and genera, and even other species of Pseudomonas (such as P. fluorescens, P. indica, $P$. alcaligenes, $P$. otidis, $P$. putida, etc.). In any case, apart from $P$. aeruginosa, neither of these microorganisms is known to be associated to CF pulmonary infections. The probe Ilim569 presents an elevated theoretical specificity (100\%), being sensitive to detect seven from a total of only eight I. limosus strains deposited in the database, and thus, showing a sensitivity of $87.5 \%$. Indeed, the low number of I. limosus rRNA sequences deposited in the database reflects the well-recognized difficulty in the isolation of this recently characterized microorganism (Bittar and Rolain, 2010; Coenye et al., 2002). This suggests the need to continuously reassess the sequences that are in use for this microorganism, as the databases are continuously being updated. By checking the Probe Match program for this probe, it was possible to observe that Ilim569 could also detect other but non-related CF organisms, such as alpha proteobacterium, agrobacterium sp., and Inquilinus ginsengisoli. The remaining eight non-targets were non-identified species from the genus Inquilinus, which may possibly also belong to the limosus species.

\section{Probes Specificity and Sensitivity Testing}

To assess the experimental specificity and sensitivity of each probe, the hybridization procedure was carried out at the optimal 


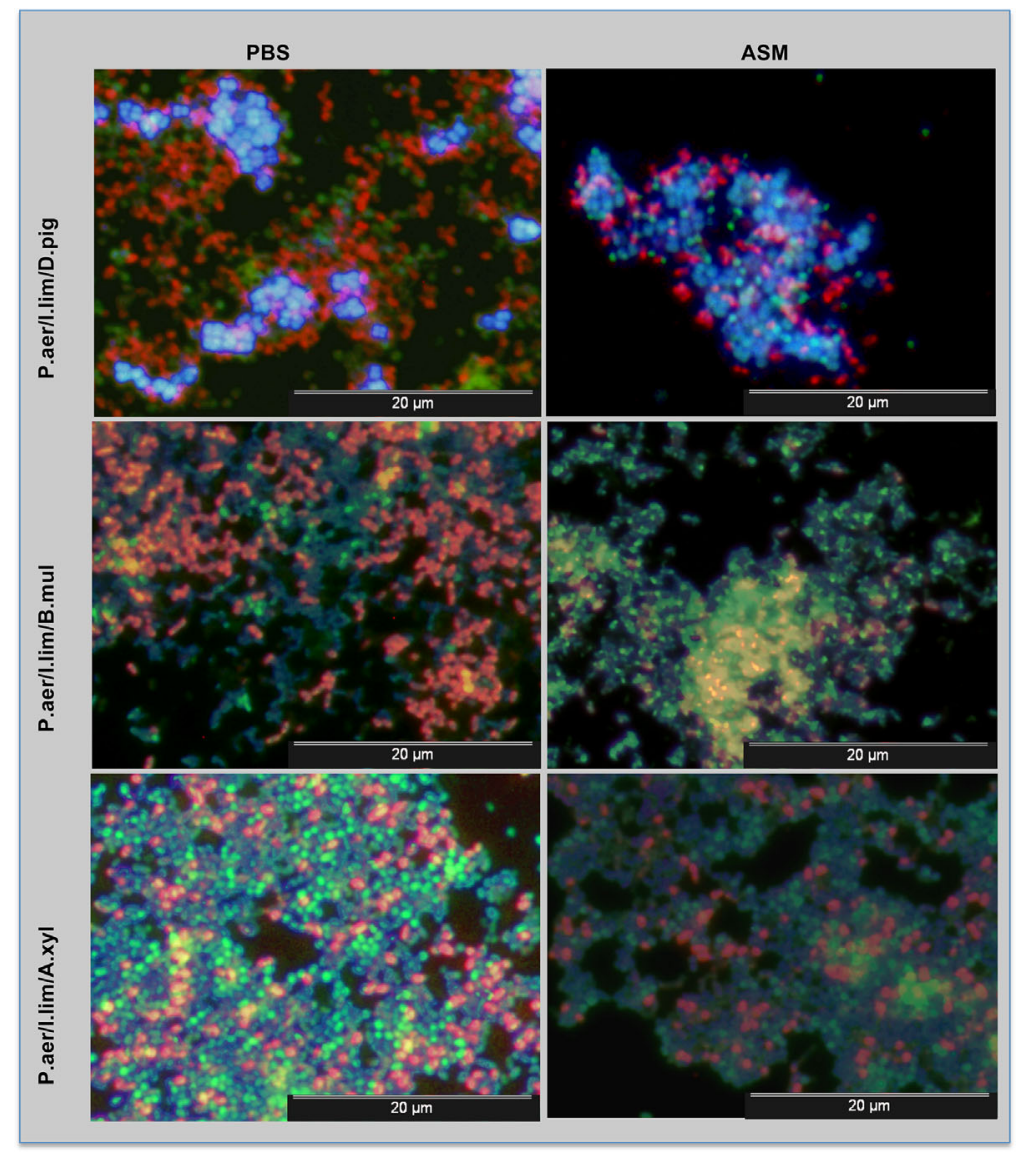

Figure 3. Multiplex FISH assay for three-species smears in phosphate-buffer solution (PBS, left column) and in artificial sputum medium (ASM, right column), using the two PNA probes (Paer565 and llim569) and DAPI staining. Each row corresponds to mixed-species populations encompassing P. aeruginosa (P.aer, red cells), I. limosus (I.lim, green cells), and a third species (D. pigrum-D.pig; B. multivorans-B.mul; and A. xylosoxidans-A.xyl), which were stained blue.

temperature previously determined $\left(65^{\circ} \mathrm{C}\right)$ against a panel of distinct bacterial strains, including taxonomically related organisms and even CF-associated bacteria (Table II).

All $P$. aeruginosa strains, including the clinical isolates and also a mucoid strain (P. aeruginosa ATCC 39324), could be easily detected by the Paer565 probe, showing a strong red fluorescent signal under microscopy. No hybridization outcome was found for the closely related species $P$. fluorescens, $P$. putida, and $P$. fragi although some of those species (eventually not the same strains) were shown to be a target for Paer565. Finally, no cross-reactivity was observed for all the other tested organisms, demonstrating the high specificity/sensitivity found by the sequence analysis described before. Concerning the probe Ilim569, a positive FISH result was obtained for both I. limosus isolates, with the species emitting a bright green fluorescent signal after the application of the method. As an example, Figure 1 shows the identification of $P$. aeruginosa PA14 (red cells) and I. limosus M53 (green cells) when using the probes Paer565 and Ilim569, respectively, under fluorescence microscopy. The strength of the fluorescent signal provided by the fluorochromes coupled to each probe and obtained at the same exposure times, provide a precise identification of both species, with a clear observation of the rod-shaped morphology of both species. No other organisms that are frequently detected in CF samples ( $S$. aureus, Burkholderia spp., and D. pigrum) as well as any of the CF isolates could hybridize with the probes (Table II), suggesting that both probes may be effectively applied for further identification of $P$. aeruginosa and $I$. limosus within the polymicrobial populations recovered from $\mathrm{CF}$ airways.

In order to evaluate the specificity and sensitivity of the FISH probes for detection of bacteria with respect to the results of conventional microbiological culture and by DAPI counting, we performed an experiment on planktonic suspensions (in TSB) of $P$. aeruginosa and I. limosus. At certain time points, samples of each microorganism were analyzed for CFUs, total cells, and FISH counts. After microscope acquisition, FISH photographs were also analyzed using an adaptation to the image-processing software MacBiophotonics ImageJ version $1.43 \mathrm{~m}$ (Collins, 2007) for fluorescence intensity signal monitoring. For this, an automatic approach able to run in a batch-mode fashion was designed. Herein, the method was based in developing a binary mask in which the regions of interest (ROIs) (i.e., the cells) were highlighted from the background by means of a Laplacian of Gaussian (LoG) filter $(9 \times 9$ kernel). Subsequently, the binary mask was overlapped with the 
(A)
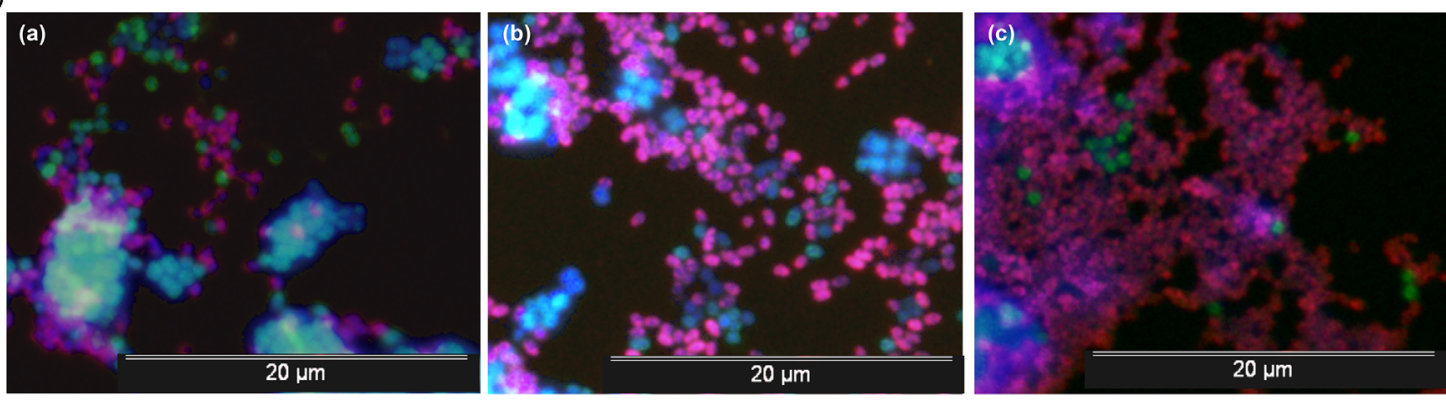

(B)

\begin{tabular}{|c|c|c|c|c|c|}
\hline \multirow[b]{2}{*}{$\begin{array}{c}\text { Corresponding } \\
\text { fluorescence } \\
\text { microscopy picture }\end{array}$} & \multicolumn{3}{|c|}{ Inoculum concentration $(\mathrm{CFU} / \mathrm{mL})$} & \multicolumn{2}{|c|}{ FISH Cells/mL } \\
\hline & P. aeruginosa & I. limosus & D. pigrum & $\begin{array}{c}\text { P. aeruginosa } \\
\text { (detected by Paer565) }\end{array}$ & $\begin{array}{c}\text { I. limosus } \\
\text { (detected by Ilim569) }\end{array}$ \\
\hline (a) & $6.15 \times 10^{8}\left( \pm 1.29 \times 10^{8}\right)$ & $5.63 \times 10^{8}\left( \pm 5.68 \times 10^{7}\right)$ & $4.98 \times 10^{8}\left( \pm 3.12 \times 10^{8}\right)$ & $1.95 \times 10^{8}\left( \pm 4.52 \times 10^{7}\right)$ & $1.83 \times 10^{8}\left( \pm 5.60 \times 10^{7}\right)$ \\
\hline (b) & $7.40 \times 10^{8}\left( \pm 1.28 \times 10^{8}\right)$ & $1.22 \times 10^{8}\left( \pm 4.24 \times 10^{6}\right)$ & $1.49 \times 10^{8}\left( \pm 2.49 \times 10^{8}\right)$ & $4.73 \times 10^{8}\left( \pm 1.23 \times 10^{8}\right)$ & $1.23 \times 10^{8}\left( \pm 8.29 \times 10^{7}\right)$ \\
\hline (c) & $9.97 \times 10^{8}\left( \pm 1.82 \times 10^{8}\right)$ & $6.20 \times 10^{7}( \pm 0)$ & $8.28 \times 10^{7}\left( \pm 2.76 \times 10^{8}\right)$ & $4.30 \times 10^{8}\left( \pm 1.61 \times 10^{8}\right)$ & $5.14 \times 10^{7}\left( \pm 1.28 \times 10^{7}\right)$ \\
\hline
\end{tabular}

Figure 4. (A) Fluorescence microscopy photographs of three-species smears of $P$. aeruginosa (red cells), I. limosus (green cells), and $D$. pigrum (blue cells) visualized by specific PNA probes Paer565, and llim569 and DAPI staining, respectively. Each picture represents different $P$. aeruginosa cells proportions in the whole population: $33 \%(\mathbf{a}), 75 \%$ (b), and $90 \%$ (c); (B) Bacterial composition of the inoculum, determined by culture and expressed by CFU/mL, and estimated number of $P$. aeruginosa and $I$. limosus detected by each PNA probe after hybridization.

original red channel and then the mean fluorescence intensity was calculated as the average of each ROI mean intensity.

As expected, PNA-FISH counts were higher than CFU, which most probably was due to the presence of non-cultivable cells, but very close to total cells as determined by DAPI (Fig. 2). Therefore, determination of CFU numbers may not reflect the true concentration of microbes within the CF samples (there is a great possibility of most species within the whole community stop growing after antibiotic treatment or even existing bacterial aggregates that are very difficult to disintegrate) (Hogardt et al., 2000). Regarding the mean intensity of the fluorescent signal, faster-growing or highly active cells (showing the highest CFU before the stationary phase-at 7 and $12 \mathrm{~h}$ for $P$. aeruginosa and $I$. limosus, respectively) tend to have more ribosomes, and hence bind proportionately more probe molecules, resulting in cells hybridized with a stronger fluorescent signal ( $\sim 160$ arbitrary fluorescence units for both cases).

\section{Hybridization in Smears}

To assess if $P$. aeruginosa and I. limosus could be easily discriminated within mixed-species populations, a multiplex PNA assay was applied to smears of both species mixed together with other CF-related organisms such as Burkholderia multivorans, A. xylosoxidans, and D. pigrum. B. multivorans is a prominent and one of the predominant bacteria from all currently defined BCC species that have been cultured from CF sputum
(Mahenthiralingam et al., 2001; Reik et al., 2005). It poses a serious health threat to $\mathrm{CF}$ patients, causing a form of septicemia known as "cepacia syndrome" (Zahariadis et al., 2003) and presenting innate, and acquired multiple resistance face to the selected pressure by antibiotics (Stokell et al., 2013). A. xylosoxidans and $D$. pigrum have been detected in the airways of $\mathrm{CF}$ in the last few years. In patients with $\mathrm{CF}$, an increasing detection of $A$. xylosoxidans and D. pigrum has recently been reported (Bittar et al., 2008b; Kanellopoulou et al., 2004; Raso et al., 2008; Saiman et al., 2001), but the clinical significance of both species infection is still not clarified due to the scarcity of data on its impact and transmissibility. However, several lines of investigation have supported signals for their adaptation and their possible contributions to the lung disease chronicity (Hansen et al., 2010; Lopes et al., 2012, 2015).

In this study, the identification of the third organism within the mixed-species smears was possible by counterstaining the samples with the non-specific dye DAPI at the end of the hybridization process. In Figure 3 , it is possible to accurately differentiate between the different species when the bacteria were suspended either in PBS (left column) or in ASM (right column), with the species presenting similar proportions within the whole population. The clear-cut discrimination in smears of P. aeruginosa and I. limosus, provided by the application of the multicolor FISH method described in here, highlights the practicability and reliability of this technique in rapidly detecting a broad spectrum of microorganisms (including classical and emergent) in specimens of CF patients. 

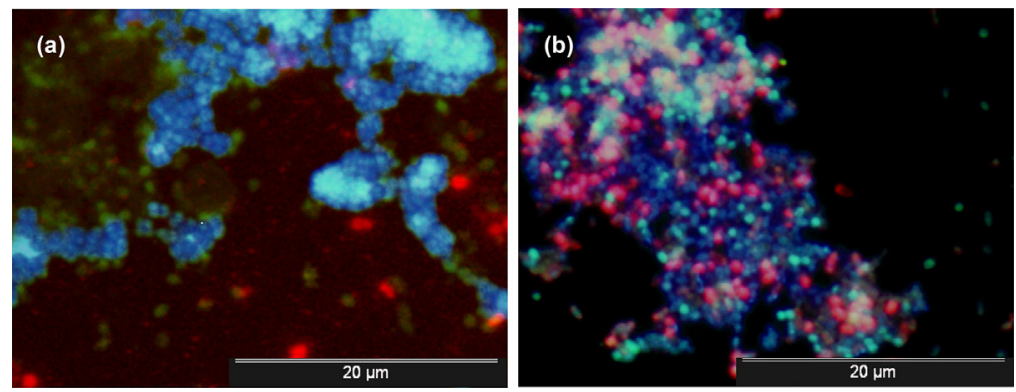

Figure 5. PNA-FISH applied to sputum clinical samples artificially contaminated with three-species encompassing: $P$. aeruginosa, I. limosus, and $D$. pigrum (a) and $P$. aeruginosa, I. limosus, and A. xylosoxidans $(\mathbf{b})$. P. aeruginosa cells are stained red by Paer565 PNA probe; I. limosus cells are stained green by llim569 PNA probe, and the third organism (D. pigrum or A. xylosoxidans) are both stained blue by DAPI staining.

After employing the FISH technique in PBS and ASM samples of the three-species and to evaluate the practicability of the method, we examined the limit in the detection in the presence of a large excess of one species (P. aeruginosa). For this, we performed a FISH experiment with a mixture of $P$. aeruginosa, I. limosus, and
D. pigrum in equal $(\sim 33 \%)$ and in different proportions, with $P$. aeruginosa ranging between $\sim 75 \%$ and $90 \%$. The concentration of inoculated bacteria was determined by conventional plating techniques (as $\mathrm{CFU} / \mathrm{mL}$ ) and a quantitative analysis was further performed for P. aeruginosa and I. limosus cells after hybridization

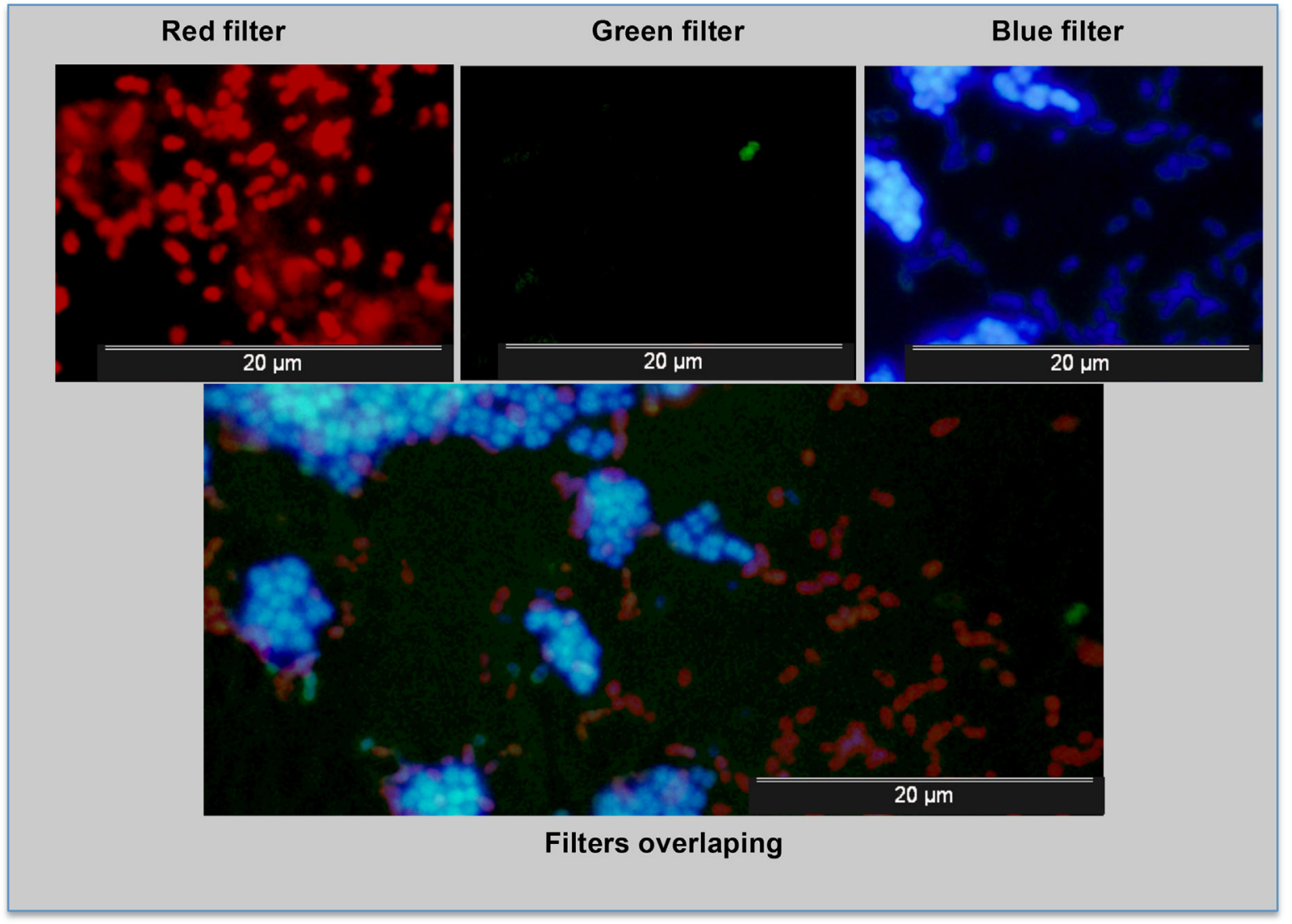

Figure 6. Multiplex PNA assay applied to the three-species $24 \mathrm{~h}$-old biofilms formed by $P$. aeruginosa, I. limosus, and $D$. pigrum on PS coupons. The different channels enable to visualize the species involved in the consortium, according with the fluorochromes used (Alexa fluor 594, red: P. aeruginosa; Alexa Fluor 488, green: I. limosus; DAPI, blue: all species). The bands superposition discriminating the different species within the consortium is (bottom row) allows observing that the biofilm is mainly composed by $P$. aeruginosa and $D$. pigrum, with I. limosus as the lowest representative population. 
with the Paer565 and Ilim569 probes, respectively. It was possible to conclude the estimated number of each bacterium within the whole populations was not entirely in accordance with the number of bacterial cells present in the inoculum (likely because of the standard deviations), but cell numbers in the same magnitude orders were detected by both PNA probes, allowing us to ensure about the potential of PNA-FISH as an effective quantitative tool (Fig. 4).

\section{FISH Applied to Clinical Sputum Samples and to Biofilms}

FISH using labeled fluorescent PNA probes is a methodology that has been successfully applied in many fields of microbiology, but while few studies have focused on its application to CF (Brown and Govan, 2007; Kirketerp-Moller et al., 2008; Malic et al., 2009; Rudkjobing et al., 2012; Wellinghausen et al., 2006; Yang et al., 2008) most only report the identification of traditional CFpathogens, preventing an accurate identification of the complex microbial ecology present within the $\mathrm{CF}$ environment and subsequently a full understanding of the bacterial interactions occurring in situ as well as the interplay of these communities in the host. Considering the application of PNA-FISH method in clinical settings, we successfully validated the developed PNA probes to identify and differentiate mixed-species cultures of $P$. aeruginosa, $I$. limosus, and D. pigrum or A. xylosoxidans in artificially contaminated clinical sputum samples (Fig. 5), with results clearly showing a strong discrimination between all species in the mixedcultures. Although, these results need to be confirmed in a larger series of cases, they indicate that PNA-FISH is applicable to clinical samples and may be useful, for instance, for the selection of the most adequate antibiotic treatment to be used for bacterial eradication, depending on the infecting species.

The establishment of bacterial biofilms in the CF lungs is becoming an increasing problematic (Bjarnsholt et al., 2009; Worlitzsch et al., 2002), as the bacteria are well adapted to the environment and protected from the host immune system, developing persistent chronic infections due to the ineffectiveness of antibiotic treatment (Hogardt and Heesemann, 2010; Moskowitz et al., 2004). It is believed that FISH may be useful for the rapid detection of microorganisms that cause acute or even chronic pulmonary infections, supporting an adequate pathogen-directed antibiotic therapy for patients with exacerbations and eventually improving strategies for a better control of these consortia. When applied to biofilms, FISH allows providing information not only about the specific detection and discrimination between the biofilm-forming bacterial species, but also concerning cell count and cell morphology. Moreover, it is possible to observe the in situ spatial distribution and arrangement of the bacterial cells within the consortia without biofilm disruption, leading to a better understanding of the real bacterial interactions occurring in these polymicrobial consortia (Almeida et al., 2011).

As for mixed-species smears, a multiplex PNA probing assay was addressed in three-species biofilms developed on PS surfaces and encompassing P. aeruginosa, I. limosus, and D. pigrum. In Figure 6, it can be seen that all microorganisms could be easily distinguished with distinct cell wall characteristics in the multiplex experiment. The strength of each fluorescent signal enabled to visualize and discriminate $P$. aeruginosa (red cells, image on top left), I. limosus (green cells, image on top center) within the consortia, while $D$. pigrum can be identified by DAPI (blue cells, image on top right). The superposition of the filters (bottom image) allowed observing the distribution of the microorganisms within the consortium, resulting in an accurate identification and distinction of each species. Interestingly, the consortium was dominated not only by $P$. aeruginosa but also by $D$. pigrum, with $I$. limosus representing the smallest population. These results were corroborated by culture methods, using non- and selective agar media (average CFU numbers, per $\mathrm{cm}^{2}$, were $8.3 \times 10^{6}\left( \pm 3.6 \times 10^{5}\right)$ for $P$. aeruginosa, $4.2 \times 10^{7}\left( \pm 1.7 \times 10^{7}\right)$ for D. pigrum, and $2.9 \times 10^{5}\left( \pm 1.2 \times 10^{5}\right)$ for I. limosus). Therefore, the low proportion of I. limosus within the biofilm seems to indicate that this species was outcompeted by the $P$. aeruginosa and/or $D$. pigrum. It is suggested that the preponderance of $D$. pigrum in the biofilm could be decisive to decline I. limosus, with the first species also triggering sensitivity to a large number of antibiotics to the whole biofilm (Lopes et al., unpublished data). The ability of these emergent species to develop multidrug-resistant biofilms alone and in modulating social interactions with $P$. aeruginosa was addressed before (Lopes et al., 2012, 2014). Altogether, these results highlight the significance of emergent species in CF infection and therapeutics, and should not be therefore, disregarded.

Certainly that these and other interactions occurring between bacterial species involved in CF mixed infections could be fully understood with the applicability of FISH in biofilms formed in the conditions found in CF lungs.

\section{Conclusions}

The use of molecular methods, such as the PNA-FISH, for the identification of bacteria in CF samples, has revealed that the complexity and microbial diversity of CF airways is greater than that found by culturing. In here, the PNA probes designed to detect $P$. aeruginosa and I. limosus yielded high specificities and sensitivities to identify the corresponding target microorganisms. The versatility and the fast procedure, taking no longer that $3 \mathrm{~h}$, make FISH a valuable tool for the rapid diagnosis of bacteria in CF samples. The multiplexed PNA-FISH assay, counterstained with DAPI, was successfully applied directly in mixed-species biofilms, enabling an accurate identification of the bacteria involved in the consortia. The method also allows the in situ microscopic visualization of the biofilm structure, which might facilitate the understanding of the real complex interactions between the species. While this work gives awareness on the potentialities of a multiplex approach of PNA-FISH, it is of extreme importance the employment of PNA-FISH in clinical specimens. This will be certainly useful to examine/confirm several important CF-old enigmas, namely: (i) the spatial distribution and arrangement of bacterial species inhabiting CF airways; (ii) the prevailing and non-dominant bacterial species within the consortium; (iii) possible synergism or even the competition interactions provided by the bacterial species; and (iv) eventual alterations in the structure and composition of the mixed-species communities.

The authors acknowledge to the Portuguese Foundation for Science and Technology (FCT), under the scope of the strategic funding of UID/BIO/04469/2013 and 
UID/EQU/00511/2013-LEPABE units and to the COMPETE 2020 (POCI-01-0145FEDER-006684). This study was also supported by FCT and the European Community fund FEDER, through Program COMPETE, under the scope of the Projects "DNA mimics" PIC/IC/82815/2007, RECI/BBB-EBI/0179/2012 (FCOMP01-0124-FEDER-027462), "BioHealth-Biotechnology and Bioengineering approaches to improve health quality," Ref. NORTE-07-0124-FEDER-000027 and NORTE-07-0124-FEDER-000025-RL2_ Environment \& Health, co-funded by the Programa Operacional Regional do Norte (ON.2-O Novo Norte), QREN, FEDER. The authors also acknowledge the grant of Susana P. Lopes Contract post-doc fellowship: SFRH/BPD/95616/2013 (supported by FCT) and of the COST-Action TD1004: Theragnostics for imaging and therapy. The authors would also like to thanks to Dr Michael Surette (University of Calgary, Canada) for kindly provide $I$. limosus strain, and also to Hospital de Braga (Braga, Portugal) for the clinical sputum samples.

\section{References}

Almeida C, Azevedo NF, Fernandes RM, Keevil CW, Vieira MJ. 2010. Fluorescence in situ hybridization method using a peptide nucleic acid probe for identification of Salmonella spp. in a broad spectrum of samples. Appl Environ Microbiol 76:4476-4485.

Almeida C, Azevedo NF, Santos S, Keevil CW, Vieira MJ. 2011. Discriminating multispecies populations in biofilms with peptide nucleic acid fluorescence in situ hybridization (PNA FISH). PLoS ONE 6:e14786.

Amann R, Fuchs BM. 2008. Single-cell identification in microbial communities by improved fluorescence in situ hybridization techniques. Nat Rev Microbiol 6:339-348.

Amann RI, Ludwig W, Schleifer KH. 1995. Phylogenetic identification and in situ detection of individual microbial cells without cultivation. Microbiol Rev 59:143-169.

Anuj SN, Whiley DM, Kidd TJ, Bell SC, Wainwright CE, Nissen MD, Sloots TP. 2009. Identification of Pseudomonas aeruginosa by a duplex real-time polymerase chain reaction assay targeting the ecfX and the gyrB genes. Diagn Microbiol Infect Dis 63:127-131.

Ashelford KE, Weightman AJ, Fry JC. 2002. PRIMROSE: A computer program for generating and estimating the phylogenetic range of $16 \mathrm{~S}$ rRNA oligonucleotide probes and primers in conjunction with the RDP-II database. Nucleic Acids Res 30:3481-3489.

Aslanzadeh J. 2004. Preventing PCR amplification carryover contamination in a clinical laboratory. Ann Clin Lab Sci 34:389-396.

Azevedo NF, Almeida C, Cerqueira L, Dias S, Keevil CW, Vieira MJ. 2007. Coccoid form of Helicobacter pylori as a morphological manifestation of cell adaptation to the environment. Appl Environ Microbiol 73:3423-3427.

Azevedo NF, Jardim T, Almeida C, Cerqueira L, Almeida AJ, Rodrigues F, Keevil CW, Vieira MJ. 2011. Application of flow cytometry for the identification of Staphylococcus epidermidis by peptide nucleic acid fluorescence in situ hybridization (PNA FISH) in blood samples. Antonie Van Leeuwenhoek 100:463-470.

Barenfanger J, Drake C, Kacich G. 1999. Clinical and financial benefits of rapid bacterial identification and antimicrobial susceptibility testing. J Clin Microbiol 37:1415-1418.

Bittar F, Leydier A, Bosdure E, Toro A, Reynaud-Gaubert M, Boniface S, Stremler N, Dubus JC, Sarles J, Raoult D, Rolain JM. 2008a. Inquilinus limosus and cystic fibrosis. Emerg Infect Dis 14:993-995.

Bittar F, Richet H, Dubus JC, Reynaud-Gaubert M, Stremler N, Sarles J, Raoult D, Rolain JM. 2008b. Molecular detection of multiple emerging pathogens in sputa from cystic fibrosis patients. PLoS ONE 3:e2908.

Bittar F, Rolain JM. 2010. Detection and accurate identification of new or emerging bacteria in cystic fibrosis patients. Clin Microbiol Infect 16: 809-820.

Bjarnsholt T, Jensen PO, Fiandaca MJ, Pedersen J, Hansen CR, Andersen CB, Pressler T, Givskov M, Hoiby N. 2009. Pseudomonas aeruginosa biofilms in the respiratory tract of cystic fibrosis patients. Pediatr Pulmonol 44: $547-558$.

Bousbia S, Raoult D, La Scola B. 2013. Pneumonia pathogen detection and microbial interactions in polymicrobial episodes. Future Microbiol 8: $633-660$
Brown AR, Govan JR. 2007. Assessment of fluorescent in situ hybridization and PCR-based methods for rapid identification of Burkholderia cepacia complex organisms directly from sputum samples. J Clin Microbiol 45: 1920-1926.

Burns JL, Emerson J, Stapp JR, Yim DL, Krzewinski J, Louden L, Ramsey BW, Clausen CR. 1998. Microbiology of sputum from patients at cystic fibrosis centers in the United States. Clin Infect Dis 27:158-163.

Call DR, Borucki MK, Loge FJ. 2003. Detection of bacterial pathogens in environmental samples using DNA microarrays. J Microbiol Methods 53: 235-243.

Carmody LA, Zhao J, Schloss PD, Petrosino JF, Murray S, Young VB, Li JZ, LipPuma JJ. 2013. Changes in cystic fibrosis airway microbiota at pulmonary exacerbation. Ann Am Thorac Soc 10:179-187.

Cerqueira L, Azevedo NF, Almeida C, Jardim T, Keevil CW, Vieira MJ. 2008. DNA mimics for the rapid identification of microorganisms by fluorescence in situ hybridization (FISH). Int J Mol Sci 9:1944-1960.

Cerqueira L, Fernandes RM, Ferreira RM, Carneiro F, Dinis-Ribeiro M, Figueiredo C, Keevil CW, Azevedo NF, Vieira MJ. 2011. PNA-FISH as a new diagnostic method for the determination of clarithromycin resistance of Helicobacter pylori. BMC Microbiol 11:101.

Chadwick N, Bruce I, Davies M, van Gemen B, Schukkink R, Khan K, Pounder R, Wakefield A. 1998. A sensitive and robust method for measles RNA detection. J Virol Methods 70:59-70.

Chiron R, Marchandin H, Counil F, Jumas-Bilak E, Freydiere AM, Bellon G, Husson MO, Turck D, Bremont F, Chabanon G, Segonds C. 2005. Clinical and microbiological features of Inquilinus sp. isolates from five patients with cystic fibrosis. J Clin Microbiol 43:3938-3943.

Cleven BE, Palka-Santini M, Gielen J, Meembor S, Kronke M, Krut O. 2006. Identification and characterization of bacterial pathogens causing bloodstream infections by DNA microarray. J Clin Microbiol 44:2389-2397.

Coenye T, Goris J, Spilker T, Vandamme P, LiPuma JJ. 2002. Characterization of unusual bacteria isolated from respiratory secretions of cystic fibrosis patients and description of Inquilinus limosus gen. nov., sp. nov. J Clin Microbiol 40:2062-2069.

Cole JR, Chai B, Farris RJ, Wang Q, Kulam SA, McGarrell DM, Garrity GM, Tiedje JM. 2005. The Ribosomal Database Project (RDP-II): Sequences and tools for highthroughput rRNA analysis. Nucleic Acids Res 33:D294-D296.

Collins TJ. 2007. ImageJ for microscopy. Biotechniques 43:25-30.

Conrad D, Haynes M, Salamon P, Rainey PB, Youle M, Rohwer F. 2013. Cystic fibrosis therapy: A community ecology perspective. Am J Respir Cell Mol Biol 48:150-156.

Cooke RP, O’Neill WA, Xu J, Moore JE, Elborn JS. 2007. Inquilinus limosus isolated from a cystic fibrosis patient: First UK report. Br J Biomed Sci 64:127-129.

Costello A, Herbert G, Fabunmi L, Schaffer K, Kavanagh KA, Caraher EM, Callaghan M, McClean S. 2011. Virulence of an emerging respiratory pathogen, genus Pandoraea, in vivo and its interactions with lung epithelial cells. J Med Microbiol 60:289-299.

Coull J, Hyldig-Nielsen JJ. 2003. US Patent 6664045. PNA probes, probe sets, methods and kits pertaining to the detection of microorganisms.

Dalboge CS, Hansen CR, Pressler T, Hoiby N, Johansen HK. 2011. Chronic pulmonary infection with Stenotrophomonas maltophilia and lung function in patients with cystic fibrosis. J Cyst Fibros 10:318-325.

Davies JC, Bilton D. 2009. Bugs, biofilms, and resistance in cystic fibrosis. Respir Care 54:628-640.

Fernandez-Olmos A, Garcia-Castillo M, Morosini MI, Lamas A, Maiz L, Canton R. 2012. MALDI-TOF MS improves routine identification of non-fermenting gram negative isolates from cystic fibrosis patients. J Cyst Fibros 11:59-62.

Galluzzi L, Magnani M, Saunders N, Harms C, Bruce IJ. 2007. Current molecular techniques for the detection of microbial pathogens. Sci Pro 90:29-50.

Giesen U, Kleider W, Berding C, Geiger A, Orum H, Nielsen PE. 1998. A formula for thermal stability $(\mathrm{Tm})$ prediction of PNA/DNA duplexes. Nucleic Acids Res 26:5004-5006.

Gomez MI, Prince A. 2007. Opportunistic infections in lung disease: Pseudomonas infections in cystic fibrosis. Curr Opin Pharmacol 7:244-251.

Guimarães N, Azevedo NF, Figueiredo C, Keevil CW, Vieira MJ. 2007. Development and application of a novel peptide nucleic acid probe for the specific detection of Helicobacter pylori in gastric biopsy specimens. J Clin Microbiol 45:3089-3094. 
Guss AM, Roeselers G, Newton IL, Young CR, Klepac-Ceraj V, Lory S, Cavanaugh CM. 2011. Phylogenetic and metabolic diversity of bacteria associated with cystic fibrosis. ISME J 5:20-29.

Hansen CR, Pressler T, Nielsen KG, Jensen P0, Bjarnsholt T, Hoiby N. 2010. Inflammation in Achromobacter xylosoxidans infected cystic fibrosis patients. J Cyst Fibros 9:51-58.

Hiyari S, Bennett KM. 2011. Dental diagnostics: Molecular analysis of oral biofilms. J Dent Hyg 85:256-263.

Hogardt M, Heesemann J. 2010. Adaptation of Pseudomonas aeruginosa during persistence in the cystic fibrosis lung. Int J Med Microbiol 300:557-562.

Hogardt M, Trebesius K, Geiger AM, Hornef M, Rosenecker J, Heesemann J. 2000. Specific and rapid detection by fluorescent in situ hybridization of bacteria in clinical samples obtained from cystic fibrosis patients. J Clin Microbiol 38:818-825.

Hoiby N. 2011. Recent advances in the treatment of Pseudomonas aeruginosa infections in cystic fibrosis. BMC Med 9:32.

Hugenholtz P. 2002. Exploring prokaryotic diversity in the genomic era. Genome Biol 3:reviews0003-reviews0003.0008.

Josten M, Reif M, Szekat C, Al-Sabti N, Roemer T, Sparbier K, Kostrzewa M, Rohde H, Sahl HG, Bierbaum G. 2013. Analysis of the matrix-assisted laser desorption ionization-time of flight mass spectrum of Staphylococcus aureus identifies mutations that allow differentiation of the main clonal lineages. J Clin Microbiol 51:1809-1817.

Kanellopoulou M, Pournaras S, Iglezos H, Skarmoutsou N, Papafrangas E, Maniatis AN. 2004. Persistent colonization of nine cystic fibrosis patients with an Achromobacter (Alcaligenes) xylosoxidans clone. Eur J Clin Microbiol Infect Dis 23:336-339.

Kidd TJ, Ramsay KA, Hu H, Bye PT, Elkins MR, Grimwood K, Harbour C, Marks GB, Nissen MD, Robinson PJ, Rose BR, Sloots TP, Wainwright CE, Bell SC. 2009. Low rates of Pseudomonas aeruginosa misidentification in isolates from cystic fibrosis patients. J Clin Microbiol 47:1503-1509.

Kirketerp-Moller K, Jensen PO, Fazli M, Madsen KG, Pedersen J, Moser C, TolkerNielsen T, Hoiby N, Givskov M, Bjarnsholt T. 2008. Distribution, organization, and ecology of bacteria in chronic wounds. J Clin Microbiol 46:2717-2722

Lambiase A, Del Pezzo M, Cerbone D, Raia V, Rossano F, Catania MR. 2013. Rapid identification of Burkholderia cepacia complex species recovered from cystic fibrosis patients using matrix-assisted laser desorption ionization time-of-flight mass spectrometry. J Microbiol Methods 92:145-149.

Lambiase A, Raia V, Del Pezzo M, Sepe A, Carnovale V, Rossano F. 2006. Microbiology of airway disease in a cohort of patients with cystic fibrosis. BMC Infect Dis 6:4.

Lipuma JJ. 2010. The changing microbial epidemiology in cystic fibrosis. Clin Microbiol Rev 23:299-323.

Lopes SP, Azevedo NF, Pereira MO. 2014. Emergent bacteria in cystic fibrosis: In vitro biofilm formation and resilience under variable oxygen conditions. Biomed Res Int 2014:678301. doi: 10.1155/2014/678301

Lopes SP, Azevedo NF, Pereira MO. 2015. Microbiome in cystic fibrosis-Shaping polymicrobial interactions for advances in antibiotic therapy. Crit Rev Microbiol 41:353-365.

Lopes SP, Ceri H, Azevedo NF, Pereira MO. 2012. Antibiotic resistance of mixed biofilms in cystic fibrosis: Impact of emerging microorganisms on treatment of infection. Int J Antimicrob Agents 40:260-263.

Lynch SV, Bruce KD. 2013. The cystic fibrosis airway microbiome. Cold Spring Harb Perspect Med 3:a009738.

Magalhães AP, Azevedo NF, Pereira MO, Lopes SP. 2016. The cystic fibrosis microbiome in an ecological perspective and its impact in antibiotic therapy. Appl Microbiol Biotechnol 100:1163-1181.

Mahenthiralingam E, Vandamme P, Campbell ME, Henry DA, Gravelle AM, Wong LT, Davidson AG, Wilcox PG, Nakielna B, Speert DP. 2001. Infection with Burkholderia cepacia complex genomovars in patients with cystic fibrosis: Virulent transmissible strains of genomovar III can replace Burkholderia multivorans. Clin Infect Dis 33:1469-1475.

Malic S, Hill KE, Hayes A, Percival SL, Thomas DW, Williams DW. 2009. Detection and identification of specific bacteria in wound biofilms using peptide nucleic acid fluorescent in situ hybridization (PNA FISH). Microbiol 155:2603-2611.

Moskowitz SM, Foster JM, Emerson J, Burns JL. 2004. Clinically feasible biofilm susceptibility assay for isolates of Pseudomonas aeruginosa from patients with cystic fibrosis. J Clin Microbiol 42:1915-1922.
Mothershed EA, Whitney AM. 2006. Nucleic acid-based methods for the detection of bacterial pathogens: Present and future considerations for the clinical laboratory. Clin Chim Acta 363:206-220.

Nielsen PE. 2001. Peptide nucleic acid: A versatile tool in genetic diagnostics and molecular biology. Curr Opin Biotechnol 12:16-20.

Nielsen PE, Egholm M, Berg RH, Buchardt 0. 1991. Sequence-selective recognition of DNA by strand displacement with a thymine-substituted polyamide. Science 254:1497-1500.

Oliver JD. 2005. The viable but nonculturable state in bacteria. J Microbiol 43:93-100.

Oosterheert JJ, van Loon AM, Schuurman R, Hoepelman AI, Hak E, Thijsen S, Nossent G, Schneider MM, Hustinx WM, Bonten MJ. 2005. Impact of rapid detection of viral and atypical bacterial pathogens by real-time polymerase chain reaction for patients with lower respiratory tract infection. Clin Infect Dis 41:1438-1444.

Peleg AY, Tilahun Y, Fiandaca MJ, D’Agata EM, Venkataraman L, Moellering RC Jr, Eliopoulos GM. 2009. Utility of peptide nucleic acid fluorescence in situ hybridization for rapid detection of Acinetobacter spp. and Pseudomonas aeruginosa. J Clin Microbiol 47:830-832.

Perry-0'Keefe H, Rigby S, Oliveira K, Sorensen D, Stender H, Coull J, Hyldig-Nielsen JJ. 2001. Identification of indicator microorganisms using a standardized PNA FISH method. J Microbiol Methods 47:281-292.

Pitulle C, Citron DM, Bochner B, Barbers R, Appleman MD. 1999. Novel bacterium isolated from a lung transplant patient with cystic fibrosis. J Clin Microbiol 37:3851-3855.

Pompilio A, Crocetta V, Confalone P, Nicoletti M, Petrucca A, Guarnieri S, Fiscarelli E, Savini V, Piccolomini R, Di Bonaventura G. 2010. Adhesion to and biofilm formation on IB3-1 bronchial cells by Stenotrophomonas maltophilia isolates from cystic fibrosis patients. BMC Microbiol 10:102.

Raso T, Bianco 0, Grosso B, Zucca M, Savoia D. 2008. Achromobacter xylosoxidans respiratory tract infections in cystic fibrosis patients. APMIS 116:837-841.

Ratjen FA. 2009. Cystic fibrosis: Pathogenesis and future treatment strategies. Respir Care 54:595-605.

Reik R, Spilker T, Lipuma JJ. 2005. Distribution of Burkholderia cepacia complex species among isolates recovered from persons with or without cystic fibrosis. J Clin Microbiol 43:2926-2928.

Rogers GB, Hart CA, Mason JR, Hughes M, Walshaw MJ, Bruce KD. 2003. Bacterial diversity in cases of lung infection in cystic fibrosis patients: $16 \mathrm{~S}$ ribosomal DNA (rDNA) length heterogeneity PCR and $16 \mathrm{~S}$ rDNA terminal restriction fragment length polymorphism profiling. J Clin Microbiol 41:3548-3558.

Rogers GB, Carroll MP, Serisier DJ, Hockey PM, Jones G, Bruce KD. 2004. Characterization of bacterial community diversity in cystic fibrosis lung infections by use of 16 s ribosomal DNA terminal restriction fragment length polymorphism profiling. J Clin Microbiol 42:5176-5183.

Rolain JM, Francois P, Hernandez D, Bittar F, Richet H, Fournous G, Mattenberger Y, Bosdure E, Stremler N, Dubus JC, Sarles J, Reynaud-Gaubert M, Boniface S, Schrenzel J, Raoult D. 2009. Genomic analysis of an emerging multiresistant Staphylococcus aureus strain rapidly spreading in cystic fibrosis patients revealed the presence of an antibiotic inducible bacteriophage. Biol Direct $4: 1-15$.

Rudkjobing VB, Thomsen TR, Alhede M, Kragh KN, Nielsen PH, Johansen UR, Givskov M, Hoiby N, Bjarnsholt T. 2011. True microbiota involved in chronic lung infection of cystic fibrosis patients found by culturing and 16S rRNA gene analysis. J Clin Microbiol 49:4352-4355.

Rudkjobing VB, Thomsen TR, Alhede M, Kragh KN, Nielsen PH, Johansen UR, Givskov M, Hoiby N, Bjarnsholt T. 2012. The microorganisms in chronically infected end-stage and non-end-stage cystic fibrosis patients. FEMS Immunol Med Microbiol 65:236-244.

Saiman L, Chen Y, Tabibi S, San Gabriel P, Zhou J, Liu Z, Lai L, Whittier S. 2001. Identification and antimicrobial susceptibility of Alcaligenes xylosoxidans isolated from patients with cystic fibrosis. J Clin Microbiol 39:3942-3945.

Saiman L, Siegel J. 2004. Infection control in cystic fibrosis. Clin Microbiol Rev 17:57-71.

Salvador-Garcia C, Yague-Guirao G, Pastor-Vivero MD, Saez-Nieto JA. 2013. Chronic colonization of Inquilinus limosus in a patient with cystic fibrosis: First report in Spain. Enferm Infecc Microbiol Clin 31:414-415. 
Schmoldt S, Latzin P, Heesemann J, Griese M, Imhof A, Hogardt M. 2006. Clonal analysis of Inquilinus limosus isolates from six cystic fibrosis patients and specific serum antibody response. J Med Microbiol 55:1425-1433.

Sibley CD, Rabin H, Surette MG. 2006. Cystic fibrosis: A polymicrobial infectious disease. Future Microbiol 1:53-61.

Spilker T, Uluer AZ, Marty FM, Yeh WW, Levison JH, Vandamme P, Lipuma JJ. 2008. Recovery of Herbaspirillum species from persons with cystic fibrosis. J Clin Microbiol 46:2774-2777.

Sriramulu DD, Lunsdorf H, Lam JS, Romling U. 2005. Microcolony formation: A novel biofilm model of Pseudomonas aeruginosa for the cystic fibrosis lung. J Med Microbiol 54:667-676.

Stender H. 2003. PNA FISH: An intelligent stain for rapid diagnosis of infectious diseases. Expert Rev Mol Diagn 3:649-655.

Stokell JR, Gharaibeh RZ, Steck TR. 2013. Rapid emergence of a ceftazidime-resistant Burkholderia multivorans strain in a cystic fibrosis patient. J Cyst Fibros 12:812-816.

Stressmann FA, Rogers GB, Klem ER, Lilley AK, Donaldson SH, Daniels TW, Carroll MP, Patel N, Forbes B, Boucher RC, Wolfgang MC, Bruce KD. 2011. Analysis of the bacterial communities present in lungs of patients with cystic fibrosis from American and British centers. J Clin Microbiol 49:281-291.

Thornton RB, Rigby PJ, Wiertsema SP, Filion P, Langlands J, Coates HL, Vijayasekaran S, Keil AD, Richmond PC. 2011. Multi-species bacterial biofilm and intracellular infection in otitis media. BMC Pediatr 11:94.

Trebesius K, Panthel K, Strobel S, Vogt K, Faller G, Kirchner T, Kist M, Heesemann J, Haas R. 2000. Rapid and specific detection of Helicobacter pylori macrolide resistance in gastric tissue by fluorescent in situ hybridization. Gut 46:608-614.
Ulrich M, Beer I, Braitmaier P, Dierkes M, Kummer F, Krismer B, Schumacher U, Grapler-Mainka U, Riethmuller J, Jensen PO, Bjarnsholt T, Hoiby N, Bellon G, Doring G. 2010. Relative contribution of Prevotella intermedia and Pseudomonas aeruginosa to lung pathology in airways of patients with cystic fibrosis. Thorax 65:978-984

Waters V, Atenafu EG, Lu A, Yau Y, Tullis E, Ratjen F. 2013. Chronic Stenotrophomonas maltophilia infection and mortality or lung transplantation in cystic fibrosis patients. J Cyst Fibros 12:482-486.

Wellinghausen N, Essig A, Sommerburg 0. 2005. Inquilinus limosus in patients with cystic fibrosis. Germany. Emerg Infect Dis 11:457-459.

Wellinghausen N, Wirths B, Poppert S. 2006. Fluorescence in situ hybridization for rapid identification of Achromobacter xylosoxidans and Alcaligenes faecalis recovered from cystic fibrosis patients. J Clin Microbiol 44:3415-3417.

Wolk D, Dunne WM Jr. 2011. New technologies in clinical microbiology. J Clin Microbiol 49:S62-S67.

Worlitzsch D, Tarran R, Ulrich M, Schwab U, Cekici A, Meyer KC, Birrer P, Bellon G, Berger J, Weiss T, Botzenhart K, Yankaskas JR, Randell S, Boucher RC, Doring G. 2002. Effects of reduced mucus oxygen concentration in airway Pseudomonas infections of cystic fibrosis patients. J Clin Invest 109:317-325.

Yang L, Haagensen JA, Jelsbak L, Johansen HK, Sternberg C, Hoiby N, Molin S. 2008. In situ growth rates and biofilm development of Pseudomonas aeruginosa populations in chronic lung infections. J Bacteriol 190:2767-2776.

Yang S, Rothman RE. 2004. PCR-based diagnostics for infectious diseases: Uses, limitations, and future applications in acute-care settings. Lancet Infect Dis 4:337-348.

Zahariadis G, Levy MH, Burns JL. 2003. Cepacia-like syndrome caused by Burkholderia multivorans. Can J Infect Dis 14:123-125. 